\title{
Хірургічне лікування патології аортального клапана та висхідної аорти з використанням мінімально інвазивного доступу
}

\author{
Вайда В. В., Кравченко В. І., Жеков І. І., Кравченко І. М., Лазоришинець В. В. \\ ДУ «Національний інститут серцево-судинної хірургії імені М. М. Амосова НАМН» (Київ)
}

\begin{abstract}
Враховуючи те, що застосування мінімально інвазивного доступу при корекції захворювань аортального клапана в поєднанні з патологією висхідної аорти пришвидшує функціональне відновлення пацієнтів, це питання потребує ретельного підходу та єдино правильного вибору методу лікування.

Мета роботи - аналіз результатів хірургічного лікування патології аортального клапана та висхідної аорти шляхом мінімізації операційної травми, швидкої фізичної та психосоціальної реабілітації пацієнтів.

Матеріали та методи. 3 22.02.2014 по 01.04.2018 було прооперовано 86 пацієнтів із приводу корекції аортальних вад серця у поєднанні з аневризмою висхідної аорти або без неї з використанням верхньої Ј-подібної міні-стернотомії для доступу.

Висновки. Методика корекції аортальних вад серця в поєднанні з аневризмою висхідної аорти через мініінвазивний доступ дозволяє мінімізувати хірургічну травму, забезпечити гарний косметичний ефект і може бути застосована в клінічній практиці як альтернатива серединній стернотомії.
\end{abstract}

Ключові слова: міні-стернотомія, аортальний стеноз, аневризма висхідної аорти, аортальна недостатність.

Найбільш поширеною патологією аорти є аневризма. За повідомленнями різних авторів [3], частота аневризм висхідної аорти становить 0,76-1,56\%. За даними клініки Мейо у США, цей показник у 2016 р. дорівнював 1,8-2,3\%.

Аневризми висхідної аорти становлять $45 \%$ загального числа аневризм аорти всіх локалізацій. Аневризма аорти найчастіше виникає у людей після 40 років.

Вади аортального клапана посідають провідні позиції серед усіх вад клапанного апарату серця. За даними Американської асоціації серця, смертність від клапанних вад серця в США становить близько 20000 чоловік щорічно, або 7 осіб на 100000 в популяції [4].

Аортальний стеноз є однією 3 найчастіших форм ураження клапанів серця і найпоширенішою в осіб старшого і похилого віку незалежно від статі, у людей старше 70 років зустрічається з частотою $3,9 \%$.

За останні роки мінімально інвазивні доступи все частіше запроваджуються в кардіохірургічній практиці. Враховуючи те, що застосування мінімально інвазивного доступу при корекції захворювань аортального клапана в поєднанні з патологією висхідної аорти пришвидшує функціональне відновлення пацієнтів, це питання потребує ретельного підходу та єдино правильного вибору методу лікування. Таким чином, проблема вибору доступу при хірургічному лікуванні пацієнтів із патологією аортального клапана та висхідної аорти є актуальною. Крім того, до цього часу проблема хірургічного лікування патології аортального клапана в поєднанні з аневризмою висхідної аорти з мінімаль- но інвазивного доступу недостатньо висвітлена в літературі, немає єдиної думки стосовно вибору методу корекції.

Незважаючи на очевидні переваги поздовжньої серединної стернотомії як оперативного доступу до серця при корекції аортальних вад у поєднанні з аневризмою висхідної аорти малого діаметру, в поглиблених дослідженнях останніх років повідомляється і про певні недоліки цієї методики, а сучасність вимагає від кардіохірургів уміння виконувати складні втручання 3 мінімізацією операційної травми і зі зменшенням часу, проведеного хворим у стаціонарі [2].

Мета роботи - аналіз результатів хірургічного лікування патології аортального клапана та висхідної аорти шляхом мінімізації операційної травми, швидкої фізичної та психосоціальної реабілітації пацієнтів.

Матеріали та методи. В ДУ «Національний інститут серцево-судинної хірургії імені М. М. Амосова НАМН» починаючи з 22.02.2014 ми використовували Ј-подібну міні-стернотомію для доступу при корекції як ізольованих аортальних вад, так і аортальних вад у поєднанні 3 аневризмою висхідної аорти. Станом на 01.04.2018

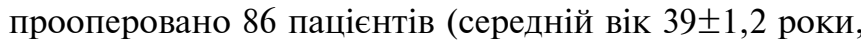
64 чоловіки та 22 жінки) з приводу корекції аортальних вад серця в поєднанні з аневризмою висхідної аорти або без неї: ізольовану заміну аортального клапана було виконано в 26 випадках, заміну аортального клапану в поєднанні з екзопротезуванням висхідної аорти виконано 43 хворим, ізольоване екзопротезування висхідної аорти на працюючому серці виконано 8 хво- 
рим, заміну аортального клапана в поєднанні з протезуванням висхідної аорти - 9 хворим.

Вік пацієнтів становив 13-68 років, у середньо-

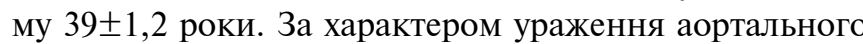
клапана пацієнти розподілилися таким чином: переважаючий аортальний стеноз мав місце у 53 пацієнтів, аортальна недостатність - у 15 хворих, а комбінована аортальна вада без явної переваги - у 10 хворих. Аневризма аорти була в межах від 4,4 до 5,6 см. В одному випадку мала місце аневризма некоронарного синусу Вальсальви (до 4,8 см) в поєднанні з різким аортальним стенозом.

Серед оперованих хворих з аневризмою висхідної аорти було 6 чоловіків і 2 жінки. Вік - 18-48 p. (у середньому 32,5 років). Тривалість операції - 140-240 хв. (середня - 163 хв.). Діаметр ВА - 4,9-5,5 см (середній 5,2 см). Крововтрата - 50-200 мл (середня - 135 мл).

У всіх пацієнтів виконано клінічні та інструментальні дослідження, що включали ЕКГ, рентгенографію органів грудної порожнини, ЕхоКГ. Проведено хронометрію загальної тривалості втручання, часу штучного кровообігу, часу затиснення аорти. Визначено об'єм інтраопераційної крововтрати, кількість гемотрансфузій в операційній і в першу післяопераційну добу. Фіксовано об'єм крововтрати на першу післяопераційну добу, тривалість механічної вентиляції, тривалість перебування у відділенні реанімації та інтенсивної терапії.

При положенні хворого на спині розріз шкіри (610 см) проводиться поздовжньо від яремної ямки до четвертого міжреберного проміжку. Грудина розсікається поздовжньо до цього ж рівня, від якого пересікається ліворуч у міжребер'ї. Після обробки країв грудини гемостатичною губкою встановлюється ретрактор. Перикард відкривається поздовжньо, із Т-подібним розсіченням у нижньому краї операційної рани. Краї перикарда фіксуються лігатурами.

Для забезпечення штучного кровообігу після введення гепарину канюлювали висхідний відділ аорти або дугу залежно від розповсюдження розширення аорти на дистальні відділи їі висхідної частини. У п’яти випадках, де проводилась операція Бенталла, виконували доступ до лівої стегнової артерії, з подальшим підключенням артеріальної лінії. Венозна канюля встановлювалася у вушко правого передсердя. Дренування лівого шлуночка виконували через гирло правої верхньої легеневої вени. Операції виконували в умовах помірної гіпотермії $\left(32^{\circ} \mathrm{C}\right)$. У всіх випадках вдавалося встановити кардіоплегічну канюлю в коронарний синус для забезпечення доставки кардіоплегічного розчину за комбінованою методикою. Після затиснення аорти та зупинки серцевої діяльності (комбінована антеретроградна кардіоплегія, «кустодіол», 10-20 мл/ кг) виконували аортотомію, ревізували уражений аортальний клапан, після видалення якого виконували його заміну штучним механічним або біопротезом. При розширеному та зміненому синотубулярному з'єднанні висхідна аорта відсікалася та імплантували попередньо зшитий кондуїт, який не огортався залишками аневризматичного мішка. У випадку необхідності корекції аневризми висхідної аорти 2-3 шви із середини некоронарної стулки і один шов із комісури між лівою та правою коронарними стулками виводили назовні аорти на тефлонових смужках. Після ушивання аорти та профілактики повітряної емболії знімали затискач з аорти і відновлювали серцеву діяльність. Поступово зігрівали хворого до природних показників. На етапі реперфузії для корекції розширення аорти виконували іiі огортання судинним протезом Gore-Tex, який фіксували до кільця протеза аортального клапана попередньо виведеними швами, і окутували всю висхідну аорту до діаметра 4,0-4,2 см. Після закінчення штучного кровообігу проводили деканюляцію порожнин серця. Встановлювали дві дренажні трубки в порожнину перикарда i ретростернально. Порожнину перикарда ушивали окремими швами. Після впевненості в гемостазі грудину фіксували чотирма окремими швами. На шкіру накладали косметичний шов.

Результати та обговорення. Всі пацієнти добре перенесли операцію. Середній час втручання склав 285 хв., коливаючись у межах 220-380 хв. Ішемічний час становив $104 \pm 28$ хв. Інтраопераційна крововтрата в усіх випадках не перевищувала 400 мл. Крововтрата в першу післяопераційну добу становила від 50 до 300 м (у середньому 125 мл). Механічна вентиляція в середньому тривала 4,5 години після втручання. Всі пацієнти були переведені з ВРІТ протягом 36 годин після операції. Слід відмітити, що у пацієнтів з екзопротезуванням виконувався Ехо-контроль (3 міс., 6 міс.): діаметр висхідної аорти не перевищував 35-37 мм, тобто міграція протеза не відмічалась у жодному випадку.

Ускладнення описаної методики були нами відзначені у 4 (4,7\%). У двох випадках ми були змушені конверсувати доступ у серединну стернотомію. В одному випадку $(1,2 \%)$ було виконано реторакотомію. Ще в одному випадку після відновлення самостійної серцевої діяльності виник стійкий атріовентрикулярний блок. Ще в одному випадку мало місце формування нориці з лігатури на грудині, що потребувало ревізії ходу нориці і висічення нитки з грудини, в цілому подовживши перебування пацієнтки в стаціонарі до 1 місяця з моменту операції. У двох хворих після переведення на другу п/о добу в умови терапевтичного стаціонару мав місце виражений больовий синдром протягом тижня із дня втручання. У решті випадків відзначено більш швидку реабілітацію таких хворих, менш виражені скарги на больові відчуття, а отже, й меншу потребу в знеболювальних.

Висновки. Методика корекції аортальних вад серця в поєднанні з аневризмою висхідної аорти через міні- 
інвазивний доступ дозволяє мінімізувати хірургічну травму, забезпечити гарний косметичний ефект і може бути застосована в клінічній практиці як альтернатива серединній стернотоміі.

\section{Література}

1. Ситар Л. Л. Аневризми грудної аорти (клініка, діагностика, лікування) / Ситар Л. Л. - Тернопіль : ТДМУ, 2011. - 167 c. - C. 83-89.

2. Минимально инвазивная хирургия сердца / под ред. Л. А. Бокерия. - М., 2008. - 92 с.
3. Dilatation of the remaining aorta after aortic valve or aortic root replacement in patients with bicuspid aortic valve: a 5-year follow-up / Bengtsson H. et al. // Ann. Thorac. Surg. - 2013. - Vol. 96. - № 1. - P. 43-49.

4. Cutler J., Yacoub M. Minimally invasive techniques in cardiac surgery // J. Thorac. Cardiovasc. Surg. - 2015. Vol. 105. - № 3. - P. 435-438.

5. Antegrade delivery of stent grafts to treat complex thoracic aortic disease / Roselli E. E., Soltesz E. G., Mastracci T. et al. // Ann Thorac Surg. - 2013. - Vol. 90. - P. 539-546. 10. 1016/j.athoracsur.2013.04.040.

\title{
Surgical treatment of the pathology of the aortic valve and ascending aorta using minimally invasive access
}

\author{
Vayda V. V., Kravchenko V. I., Zhekov I. I., Kravchenko I. M., Lazoryshynetz V. V. \\ National M. M. Amosov Institute of Cardiovascular Surgery National Academy of Medical Sciences of Ukraine (Kyiv)
}

Despite the obvious advantages of longitudinal median sternotomy as an operative access to the heart, modernity requires cardiac surgeons to perform complex interventions by minimizing surgical trauma with a decrease in time spent by patients in a hospital.

Taking into account that the application of minimally invasive access in the correction of aortic valve diseases in combination with the ascending aorta pathology accelerates the functional recovery of patients, this issue requires a careful approach and the only correct choice of treatment.

Purpose. Improvement of the results of surgical treatment of aortic valve and ascending aortic pathology by minimizing surgical trauma, rapid physical and psychosocial rehabilitation of patients.

Materials and methods. Starting from 22.02.2014 to 01.04.2018, 86 patients were treated for the correction of aortic heart disease in combination with an ascending aorta aneurysm or without using the upper J-shaped ministernotomy for access.

Conclusions. The method for correction of aortic valve defects in combination with an ascending aortic aneurysm through minimally invasive access allows to minimize surgical trauma, providing beautiful cosmetic effect and can be applied in clinical practice as an alternative to median sternotomy.

Key words: ministernomy, aortic stenosis, ascending aorta aneurysm, aortic insufficiency.

\section{Хирургическое лечение патологии аортального клапана и восходящей аорты с использованием минимально инвазивного доступа}

\author{
Вайда В. В., Кравченко В. И., Жеков И. И., Кравченко И. Н., Лазоришинец В. В. \\ ГУ «Национальный институт сердечно-сосудистой хирургии имени Н. М. Амосова НАМН» (Киев)
}

Несмотря на очевидные преимущества продольной срединной стернотомии как оперативного доступа к сердцу, современность требует от кардиохирургов умения выполнять сложные вмешательства с минимизацией операционной травмы, с уменьшением времени, проведенного больным в стационаре.

Учитывая, что применение минимально инвазивного доступа при коррекции заболеваний аортального клапана в сочетании с патологией восходящей аорты ускоряет функциональное восстановление пациентов, данный вопрос требует тщательного подхода и единственно правильного выбора метода лечения.

Цель работы - анализ результатов хирургического лечения патологии аортального клапана и восходящей аорты путем минимизации операционной травмы, быстрой физической и психосоциальной реабилитации пациентов.

Материалы и методы. С 22.02.2014 по 01.04.2018 было прооперировано 86 пациентов по поводу коррекции аортальных пороков сердца в сочетании с аневризмой восходящей аорты или без нее, с использованием верхней J-образной мини-стернотомии для доступа.

Выводы. Методика коррекции аортальных пороков сердца в сочетании с аневризмой восходящей аорты через мини-инвазивный доступ позволяет минимизировать хирургическую травму, обеспечить хороший косметический эффект и может быть применена в клинической практике как альтернатива срединной стернотомии.

Ключевые слова: мини-стернотомия, аортальный стеноз, аневризма восходящей аорты, аортальная недостаточность 